\title{
The Imaginative Struggles of Europe
}

At the birth of the European Coal and Steel Community in 1951, Robert Schuman commented of his wider vision: "it is not a question of eliminating ethnic and political borders. They are a historical given: we do not pretend to correct history, or to invent a rationalized and managed geography. What we want is to take away from borders their rigidity and what I call their intransigent hostility" (Maas 2007, 61; Geddes 2014, 290). This vision of a continent with softened, flexible borders was part of an ambitious effort to reimagine Europe in the wake of a war that had been, in the words of V. S. Pritchett, "an incessant attack upon the imagination and memory of civilised man" $(1945,11)$. The task was formidable. To reimagine Europe meant not only to search for a conceptual apparatus adequate to the comprehension of a continent but also to forge a compelling vision of a Europe entirely different from the theatre of war and atrocity that it had become. Given the scale of the challenge, the post-war project of European unification must be considered an extraordinary achievement of both politics and imagination. For while the European Union (EU) is hardly coextensive with Europe (a common slippage though that may be) its creation nonetheless entailed the powerful imagining of $a$ Europe; powerful enough to persuade former enemies to abide by supranational law, to institute (in some cases) a common currency, and indeed to soften the borders that they had spent the first part of the twentieth century hardening.

And yet, the European Union, like the idea of Europe itself, remains elusive. Among the most immanent of facts, it is nonetheless difficult to imagine or fully to comprehend: an "unfathomable mystery" (Anderson 2011, 3) or, in Jacques Delors' memorable words, an "unidentified political object" (Schmitter 1996,1 ) even to many of those who make a career of its study. ${ }^{1}$ This condition has grown only more acute in recent years as successive crises have battered the EU. Its leaders have become increasingly preoccupied by the prospect of what might be termed imaginative failure - the sense that the EU's imaginary is exhausted, uninspiring, and unfit for purpose. Crisis has pushed the EU to make polarising interventions in the lives of some of its member states, and these have in turn brought increased scrutiny of its institutions and reignited debates regarding its legitimacy. As officials have fretted over the necessity of communicating a compelling vision to the EU's citizens, those resisting its actions and policies have sought to build alternative European imaginaries with which the institutions might be challenged.

In the light of these developments, this article will explore a number of artistic interventions concerning European space and the European Union made by well-known artists and architects between 2014 and 2016. The artworks and initiatives under discussion are of two kinds. On the one hand, the article will examine installations created by architects that seek to address the European imaginary directly. These works are all related, to a greater or lesser extent, to the New Narrative for Europe, a cultural initiative of the European Parliament and European Commission; they are thus connected to a top-down strategy forged at the heart of the European project. On the other hand, the article will also examine a number of works by the street artist Banksy, made in coastal 
towns in Britain and France. These works are addressed more closely to specific situations and events but, through an exploration of European space, they also engage with the broader issue of the European imaginary. Unrelated to the EU and its institutions, Banksy's works are nonetheless, like those of the architects, also connected to larger scales - most notably the global scale of the international media.

These works will be considered in relation to a number of contemporary debates regarding mobility, borders, and art. A rapidly expanding field of study (see for example Cresswell 2006; 2014), mobility lies at the heart of the European project and is inextricably linked to notions of European citizenship and to the broader European 'imaginary'. Inevitably, discussions of mobility within Europe are frequently connected to the question of borders - a topic that has likewise received considerable scholarly attention in recent years. Border studies is now a major field of geopolitical enquiry (Van Houtum 2005) not least in relation to the complex, variable, and heterogeneous borders of Europe and the European Union (Walters 2009; Balibar 2014); part of a recent 'spatial turn' in European Studies that has led to much fruitful, interdisciplinary scholarship (Rumford 2006). There has also been increased interest in what has sometimes been termed 'border art', including efforts to interpret artworks in the light of the burgeoning literature on borders (see for example Amilhat Szary 2012; Giudice and Giubilaro 2015; Madsen 2015) and even to bring about what has been termed an "art geopolitics" (Amilhat Szary 2012). These studies often include lengthy methodological statements and interesting discussions of recent themes within border studies. However, the art itself tends to be tacked on to the end of these discussions and treated as little more than an illustration of ideas current within academic debates (and often interpreted simply in the light of the supposed intentions of the artist).

Here, I will instead attempt a less determined approach, sticking closely to the art objects themselves and considering the nature of the work that they perform as images and installations. The present study is not concerned with establishing the existence or non-existence of a specific category of 'border art.' Rather, it will explore how, through the visual thinking that is peculiar to works of art, the various installations and images under discussion have entered into an increasingly fraught debate surrounding Europe during a period in which the financial crisis, the refugee crisis, and the potential exit of the United Kingdom from the EU have all loomed large.

\section{Clacton-on-Sea}

August $28^{\text {th }}, 2014$ stands out as an important date in the run-up to the UK's referendum on EU membership. On that day, Douglas Carswell, the Member of Parliament (MP) for Clacton announced his defection from the Conservative Party to the UK Independence Party (UKIP), and stated his intention to trigger a by-election in which he would stand. On October $9^{\text {th }}$ he was returned as UKIP's first MP. The election of Carswell in this constituency, which also includes the coastal towns of Walton-on-the-Naze, Frinton-on-Sea, and Jaywick Sands, was a significant milestone for UKIP; one that seemed to show that the party could 
build on its victory in the elections to the European Parliament earlier in the year. With a probable referendum on British membership of the European Union visible on the horizon, Carswell's success seemed to bring UKIP's most cherished goal - a British exit from the EU - closer than ever before, suggesting that the party was enjoying unprecedented momentum and demonstrating that Euroscepticism could be a motivating factor beyond specifically European elections.

Yet Euroscepticism was not the only factor in the Clacton result, and nor was it per se the most important. On the same day that Douglas Carswell defected to UKIP, the Office for National Statistics reported a rise in year-on-year immigration to the UK, from 175,000 to 243,000 , with arrivals from the EU accounting for two thirds of the increase (Geddes 2014, 291). This points towards an important ingredient in UKIP's success: the "fusion strategy" pursued by its leader Nigel Farage, which "sought to merge Europe and immigration in the minds of voters, not least as an attempt to overcome the historic low salience of the EU in the minds of voters" (Ford and Goodwin 2014, 282). This had proven to be fertile terrain, on which UKIP gained traction by repeatedly drawing attention to the British government's inability to reduce immigration in the face of EU-wide freedom of movement, and by employing populist right-wing rhetoric that saw the party frequently accused of outright xenophobia (Goodwin and Milazzo 2015, 115).

As the short by-election campaign gathered pace, the Clacton parliamentary constituency, located in a quiet and little-regarded part of Essex, became the object of intense national scrutiny. This liminal ground, on which the island meets the water, found itself suddenly the focus of national debates about immigration, insularity, openness and the future of Britain. Indeed, such was the attention that, towards the end of September, the internationally acclaimed artist Bansky, once numbered by Time magazine among the world's 100 most influential people (Fairey, 2010), visited the forgotten resort of Clacton-on-Sea to stencil a mural onto a seafront boathouse (fig. 1).

This painting, promptly destroyed by the borough council on the puzzling grounds that they had received a complaint of racism, represented a migrant bird facing the hostility of local pigeons. Perched on a line, small and alone, a greenish, forked-tailed swallow seems to shrink from, and at the same time look back towards its much larger antagonists. The pigeons are mounting an organized protest and hold placards reading "migrants not welcome", "go back to Africa", and "keep off our worms." The mural makes witty play of the juxtaposition of two common uses of the term migration, with the natural migration of birds casting the politically and culturally constructed understanding of human migration in an absurd light. The pigeons' defence of risibly meagre resources - mere worms - that are in fact in abundant supply, and that swallows in any case do not eat, appears both excessive and ridiculous. Moreover, the greater size and number of the beady-eyed and puffed-up pigeons, their scraggy claws, and the manner in which they look down on the smaller bird along their sharp, accusatory beaks, all contribute to a sense of bullying and menace. 


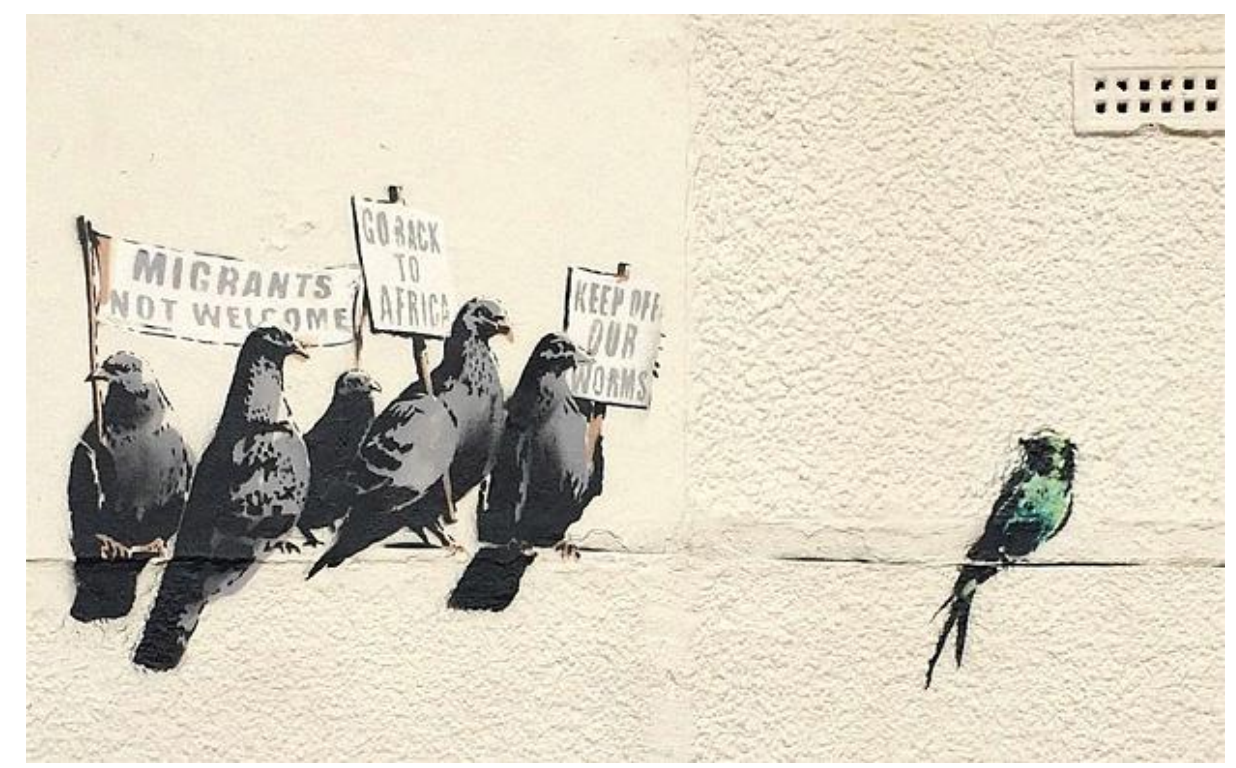

Figure 1. Banksy, mural at Clacton-on-Sea, 2014.

This small artwork perhaps offered a timely warning that the rise of UKIP risked legitimizing a form of discourse that seemed formerly to have been banished from public life, potentially eroding the gains of multiculturalism and opening the door to xenophobia. However, it seemed also to reduce the Clacton contest to a simple matter of native reaction and intolerance, sentiments represented as simultaneously sinister and laughably absurd. Such a portrayal of the town was not new. The Pet Shop Boys' surreal 1987 feature film, It Couldn't Happen Here, similarly characterizes Clacton-on-Sea as a somewhat risible bastion of narrow-mindedness. The film opens with Neil Tennant cycling along the seafront and stopping to buy postcards and tea at a kiosk. With the band's track Suburbia playing in the background, Tennant, suave in black tie and a white silk scarf, observes that throughout his life the comic and the hostile have always gone hand-in-hand. On this cue, the kiosk's owner appears, presumably a native Clactonian who, in between ogling women, subjects Tennant to a hostile rant about the lack of "decent, family-type," English holidaymakers in the town. He laments the presence of hooligans, bike-gangs and, worst of all, politicians.

This view of Clacton also informed much of the media reaction to the destruction of Banksy's mural. Coverage was split between hilarity at the assumed parochial ignorance of the "bungling" councillors, who admitted that they had no idea of the painting's monetary value, and anger at the same councillors, who were seen to have failed, on account of their parochial tastes, to appreciate the mural's artistic value. The Guardian's art critic took matters further and decried the destruction of the "best Banksy I have never seen" as a "real and vicious act of censorship" (Jones 2014). Banksy, he felt, had "exposed the truth", and created "a powerful image of our prejudiced times." That somebody could interpret the mural as racist, rather than as a critique of racism, seemed to speak more to the "cultural atmosphere of Clacton-on-Sea" than to anything else. "Clearly," he observed, "the African swallow is not a threat but an enriching presence. It is the "locals" who are grim." 
Looking at the stencil, one might be inclined to agree. Banksy's protesters are markedly unsympathetic characters. Notably, they are not the plump and elegant wood pigeons that frequent Clacton's suburban gardens but darker, feral pigeons - London pigeons in common parlance, or just "rats with wings" (Jerolmack 2008) - creatures of poor reputation and ill repute. These multitudinous, city-dwelling pigeons inhabit the bottom of the bird hierarchy in terms of human regard. Proletarian animals, with none of the perceived charm of the small and delicate sparrows that were once common in British towns and cities, feral pigeons are widely viewed as the mob, the undeserving poor of avian society, who are in fact more likely to be found scavenging for scraps than engaged in the honest labour of excavating worms. Such pigeons are highly varied in colour and pattern but in the mural their plumage is uniformly drab and contrasts markedly with the bright feathers of the smaller bird. Gulls would, perhaps, have been more appropriate for this seaside town, but these impressive, legally protected birds do not carry the same connotations, despite having themselves briefly become the subjects of recent (moral?) panic.

In spite of the widespread ridicule of the town and the speculation about the hostile character of the locals, few journalists seem to have visited. Had they done so, they might have found a scene more forlorn than menacing (notwithstanding the council's efforts to "put the fun back" into the town that they have optimistically dubbed Celebrate-on-Sea (Tendring District Council 2010)). Clacton has struggled economically since the 1980s, with a disproportionately large segment of its population out of work. In part, this reflects the fact that many of its residents are retirees. However, recent studies also found 43\% of 16-74-year-olds in Clacton to be "economically inactive", while, in the centrally-located Pier Ward, 54\% of those aged 16-64 were in receipt of out of work benefits (Centre for Social Justice 2013, 21, 20); figures on a par with some of the most crisis-hit countries of southern Europe. The town's labour market is characterised by low skills and low pay, with $41 \%$ of adults possessing no qualifications, and median household income in 2010 standing at $£ 13,648$ - not much above half of the $£ 24,242$ average for England and Wales (21). ${ }^{2}$ Clacton's B\&Bs have frequently been used as off-season temporary accommodation, sometimes bringing complex social problems into the town. Nearby Jaywick, meanwhile, was judged by the Department for Communities and Local Government (2010) to be the most deprived council ward in England.

Clacton, in other words, has an unusually high proportion of what have been dubbed the "left behinds" who form UKIP's core vote. Ford and Goodwin (2014, 278-279) characterise these as falling into two groups: those left behind economically - "older, working-class, white voters who lack the educational qualifications, incomes and skills that are needed to adapt and thrive amid a modern post-industrial economy" - and those left behind attitudinally - elderly voters wedded to "an outlook that was once seen as mainstream [but which] has become increasingly regarded as intolerant by the younger, university-educated, more socially liberal and financially secure majority who define the political consensus in early twenty-first-century Britain." Both groups are wellrepresented in Clacton. Both, also, remain something of a mystery to those who inhabit the "political consensus." Ford and Goodwin found considerable variation 
in social attitudes according to age and education and concluded that it was therefore unsurprising that "Britain's political and media class - dominated by university graduates who are often under the age of 50 years old - find UKIP voters' concerns so hard to understand. On a wide range of issues, the two groups are poles apart" (280).

Banksy's work in Clacton could thus be seen simply to mirror the values of the centre back to itself. It did not address local residents so much as the makers and consumers of national and international media - using simple terms, not unlike visual soundbites, to tell them what they already thought they knew. In this context, pigeons - widely reviled birds - functioned as an effective signifier. As Colin Jerolmack points out, throughout the western world "over the last century, pigeons have been shot, gassed, electrocuted, poisoned, trapped, and fed contraceptives, among other such efforts to repel them including spikes and sticky gel on ledges. Pigeons, more than other so-called "nuisance birds" such as starlings, are a despised species" $(2008,72)$. Moreover, Jerolmack demonstrates, with reference to the ideas of Mary Douglas (1966), that the demonization of pigeons is ultimately motivated by a sense that they are "matter out of place"; disruptive agents who, by appearing where they should not (among humans in towns and cities), draw attention to the existence of order while simultaneously signalling its failure. As Jerolmack further argues, "examining how species of animals are defined as problems can mirror and inform processes of how human groups are constructed as problematic" (2008). And in this case it is all too easy to draw a parallel between the 'out of place' pigeons and the disturbingly 'out of place' voters of Clacton, whose views had failed to keep up with demographic change.

It is perhaps surprising to encounter this use of pigeons in a work by Banksy, an artist who has repeatedly championed rats - animals which generally enjoy even lower esteem than pigeons, and which provide the most common means to denigrate pigeons by mere association - as the verminous underdogs of the urban world. ${ }^{3}$ This knowing employment of rats (which on one occasion extended to having 164 of them roaming free in a gallery) mobilises, for political purposes, precisely those creatures' lowly status and the challenge that they pose to order. Rats too constitute matter out of place - an attitude that was routinely for a long time, and often still is, also suffered by street art and graffiti. This reflection might seem to signal a puzzling contradiction when juxtaposed with the imagery of the Clacton painting. However, this should remind us that it is not the artist's attitudes or intentions that are at issue here but rather the image itself and the work that it performs.

Undoubtedly, the medium is also an important factor here: a stencil sprayed quickly onto the wall with the intention of producing a clear, hardhitting image as a move in an ongoing political contest. Nuance may well be flattened out under these circumstances and, one might argue, rightly so. After all, as the EU referendum finally approached in 2016, the Eurosceptic right did direct their campaign relentlessly towards the topic of immigration, framing the debate according to binaries every bit as crude as those displayed in the mural. In fact it is possible to understand the pigeons as referring not to Clactonians in 
general but to UKIP activists specifically - or even to Europeans in general and their treatment of non-European migrants. However, the opposite reading is also available, as both the media and the local councillors who destroyed the image (treating it as just one more example of matter out of place) certainly understood. Indeed, the council's iconoclastic gesture, in its indifference to the monetary value of the painting and its refusal to acknowledge its status as a work of art, perhaps constituted the most radical action of the entire episode.

The above analysis has focused largely on iconography and on the operation of metaphor within the image - a level on which it appears somewhat heavy-handed and overdetermined. However, the image performs other work in addition to this and it is arguably here that its real interest lies. In order to construct the minimal setting within which the drama takes place, the stencil takes advantage of its uneven ground. The line on which the birds perch utilises a pre-existing seam in the building's surface, which is only occasionally emphasised by paint. This frontier between panels of different textures forms a line that appears in some places to move behind the birds, and at other points to overlap them, to change level and to fork into separate strands, occasionally disappearing from view altogether. This insubstantial and discontinuous line seems to question the notion of natural boundaries and the sharp delineation of places, so that even as the pigeons attempt to 'hold the line' it already disintegrates beneath them.

Indeed, the division of the composition by this uneven line draws attention, by invoking place so sparingly, to the fact that the work is on one level about place; about frontiers and our powers to grant or deprive them of reality through acts of the imagination. In this sense it is important that the work itself stood at a frontier, at the very edge of the beach. Landscape impinges on consciousness here to an unusual degree, and one is intensely aware of the stark transition from land to sea. Notwithstanding the academic consensus around the inadmissibility of the idea of natural borders, one feels oneself to be at a border here. The stencil itself 'looked out' to sea - to a zone similarly divided in the simplest of manners, along a horizon separating sea from sky. The stencil's own divisions are less determined - what is the status of the vertical line in the building that separates the protagonists? How are the different textures of the surfaces to be understood? Such ambiguous treatment of place allowed this highly emplaced image to address the fact that Clacton's by-election pointed potentially not just to a reimagining of borders but to a reordering of places themselves. Looking out to sea, it also looked towards continental Europe and the other member states of the European Union. Thus, as its iconography addressed the reception of migrants from the wider world within the UK - the swallow after all has come from Africa - the image simultaneously gestured towards a coming decision regarding Britain's 'place in Europe.' As such, it touched on what has been termed the "double otherness" attached to representations of foreigners in Europe today (Balibar 2014); an otherness both European and non-European.

\section{$\underline{\text { Venice }}$}


Throughout the summer and autumn of 2014, as the Clacton by-election was played out, an installation at the architecture Biennale in Venice also sought to interrogate the nature of European space. The installation was set up by the Tomorrow, a project run by a group of architects and cultural figures based in Milan that "encourages the narration of Europe, lived by its inhabitants as a single large polycentric city." 4 The work was made in collaboration with the New Narrative for Europe, an initiative of the European Parliament and Commission that calls upon artists and intellectuals to collaborate in the formation of a new narrative for European integration. Including a cultural committee of wellknown artists and thinkers, the initiative was championed by the then president of the European Commission José Manuel Barroso, who voiced the widespread concern that peace in Europe is no longer a sufficient goal to motivate public support for the EU - either because younger generations already take peace for granted, or because it has now largely been achieved and thus constitutes not a goal but a simple matter of fact (on this see Kølvraa 2016). Barroso thus sought a new telos for the EU, and the New Narrative for Europe was to be an important step towards finding it (Battista and Setari 2014, 24).

The installation stood in the vast sixteenth-century Corderie building in the Arsenale - the complex of former shipyards and artillery workshops that had for centuries manufactured the technologies of Venetian sea power. It was situated within Monditalia, an exhibition exploring Italy's architectural modernity, which formed one of the three elements of Fundamentals, the main exhibition of the Biennale, curated by the Office for Metropolitan Architecture (OMA) with its principal, Rem Koolhaas in overall command. The final declaration of the New Narrative for Europe's cultural committee (which included Koolhaas as an associate member), entitled The Mind and Body of Europe, was presented as part of an event at the Biennale on June $5^{\text {th }}$. Additionally, it occasioned a more formal event in September - a public conversation, in which Koolhaas, Barroso, and a range of high-profile cultural figures took part. the Tomorrow was also launched at the Biennale, as a web platform that seeks to shape the European imaginary by creating a contemporary Republic of Letters. It continues to pursue this goal by initiating email exchanges between thinkers both inside and outside of Europe and publishing them on its website, where it also hosts a calendar of cultural events taking place across the continent. ${ }^{5}$ 


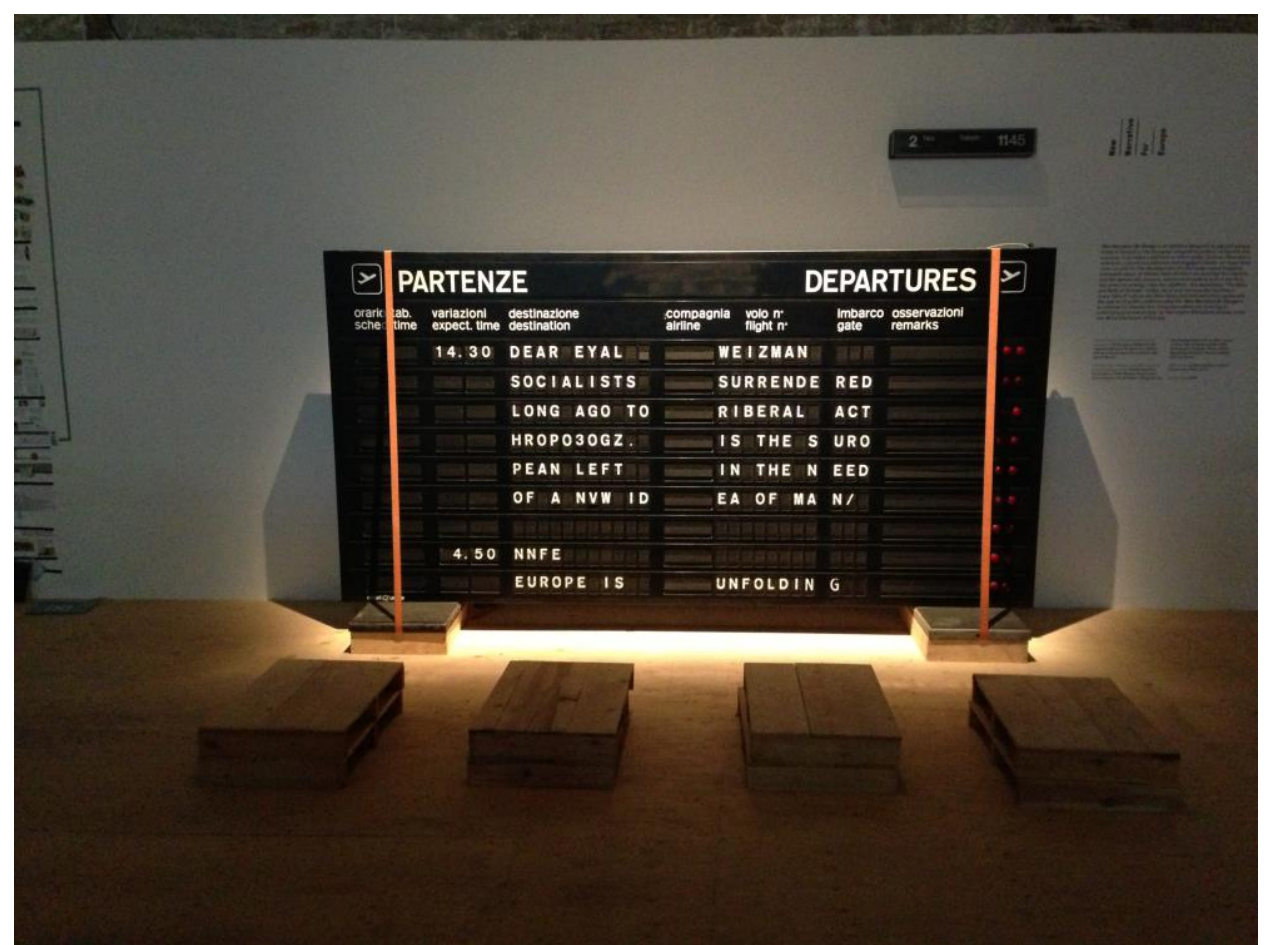

Figure 2. the Tomorrow, installation in Monditalia, Venice, 2014.

The Biennale installation by the Tomorrow (fig. 2) was made from an airport departures board of the 'split-flap' type that is sometimes referred to as a 'Solari' board, after the manufacturers Solari di Udine (who were also sponsors of the installation). For months, the board clicked and whirred in the Corderie, displaying puzzling information. Broken fragments of text came and went, recognizable sentences - questions, answers, parts of a dialogue - appeared and disappeared in an ongoing process of integration and disintegration. No departing flights were announced. Instead, many of the texts that flickered in and out of being were extracts from the email exchanges initiated by the Tomorrow as part of their new Republic of Letters. The mode of presentation took the form of writing but recalled the transience of speech, as words appeared and passed away, meanings were formed and then dissipated. Communication was presented as achievable but fragmentary and incomplete. In this sense, the installation no doubt sought to capture something of the nature of the EU itself, as an organization that is founded upon constant linguistic and cultural translation. In doing so, it seemed to embrace the poststructuralist understanding of translation as a task simultaneously possible and impossible (Derrida and Venuti 2001,178). Thus, the installation, through the unstable nature of its display, motioned towards the multilingualism of the EU while only displaying texts in English. Moreover, through the continual making and unmaking of writing, the installation also gestured to the notion of the EU as an entity whose development is realised through a succession of contestations and integrative moments. It thus brought to bear the notion that, as Bruno Latour puts it, "Europe is in itself an experiment in bricolage, a negotiated arrangement," that is interesting precisely because "it is so horribly complex, completely intertwined and negotiated" (Multiplicity 2003, 233). 
The form of the departures board - with its references to travel - was certainly apt. After all, the European Union is often characterised in terms of journeying - either as a project in need of completion or, more radically, a journey whose purpose is not to arrive but perpetually to travel. Indeed, in Zygmunt Bauman's erudite and energising account, Europe is an "unfinished adventure"; an essentially adventurous entity whose sense of adventure ought to be revived so that it might "deploy its values and the political/ethical experience of democratic self-government it has acquired, in order to assist in the substitution of a fully inclusive, universal human community for a collection of territorially entrenched entities engaged in a zero-sum game of survival" (2004, 141-2). This view of Europe's possible destiny, which has commonalities with the less colourfully argued positions of Habermas, takes explicit inspiration from Kantian cosmopolitanism while simultaneously acknowledging the flawed nature of Europe's historical universalism (and, indeed, seeking to universalise those lessons). Here we encounter the creative tension found in a number of accounts of Europe (for example Derrida 1992) between the desire to recuperate aspects of the universalising Enlightenment tradition, the necessity of acknowledging the failures and absolute limitations of that tradition, and the further desire to build a new universalism based partly on those lessons (Bialasiewicz and Elden 2006; Lindberg et al. 2014; Balibar 2014). This condition seems also to be alluded to in the installation, which assumes a projective sense of adventure and travel, and which gestures to the Enlightenment via the Republic of Letters, but which avoids any sense of univocity and finality.

The references to travel - to movement through space - signalled both that the installation was about space and that it sought knowingly to mobilise many of the discourses developed in recent years, largely but not exclusively in academic literature, around European space and the European imaginary. Travel - particularly in relation to rapid travel, freedom to travel, and flight - is at the core of the European project (with the movement of people constituting one of the 'four freedoms'). It is also one of the primary means by which European integration is experienced (McNeill 2004, 180). This experience is intimately tied to borders, which, through their apparent lack of resistance within the Schengen zone and their variable resistance at the limits of that zone, point towards a notion of citizenship based on mobility - revealing, in the process, operative orders of power. As has frequently been noted, the fading of hard borders within the Schengen zone has been accompanied by the proliferation of new types of dispersed borders, among which airports figure prominently. Indeed, "borders, which once marked the edge of clearly defined territories, are now popping up everywhere. Airports are clearly borders in vertical space" (Cresswell 2014). Our experience of borders, in other words, often takes place not at the limit of a territory but in its midst, at sites such as airports, where we submit ourselves to an unusual degree of scrutiny and control. Thus the installation, by way of the departures board, brought the border into the exhibition and signalled to the viewer (who may well have travelled to Venice by air) that their journey to the Biennale was not simply "dead time" (Creswell 2014) but was rather itself a significant act in the "making of the present" (Walters 2002) - and, in fact, of the European future. 
By displaying written exchanges, rather than flight information, the installation brought the border to the exhibition in another way. It drew attention to what have been termed Europe's "philological borders" (Balibar 2014) - the borders of the language communities that underlie the construction of imagined national communities (Anderson 1983). As Balibar has suggested, translation, in this sense, is an activity that "takes place on the border itself." Through its imperfect transgression of these philological borders, the installation seemed to bring them into question, highlighting both their permeability and their resilience. The conversations displayed (on art, politics, and culture) were themselves to be understood as points of departure; spurs to the imagination and to new modes of thought. However, the installation did not seek to reimagine Europe purely at the level of language. The work was rooted strongly in the physical world, gesturing to cross-border infrastructure - in this case a vast network of transport nodes - as something that, in the words of Angelo and Hentschel, is able to "condition the social world by shaping subjects and publics," and to act as a tool "through which people interpret large-scale change and develop a picture of their wider environment" $(2015,307)$.

In all of these senses and more, the Tomorrow's work engaged with current academic discourses surrounding European space and its reimagination and reterritorialization. The declaration of the New Narrative for Europe suggested that we might "begin to imagine Europe as one great mega-city interconnected by means of transportation and communication" (Battista and Setari 2014, 129) and this notion is certainly also at play in the installation. Indeed, it is an idea that has long been cherished by one of the Tomorrow's most prominent members, the architect and intellectual Stefano Boeri (see for example Multiplicity 2003), who also participated in a New Narrative for Europe roundtable discussion. Boeri's position on 'Europe as city' can be related, to some degree, to the idea of a "Europe of the cities", in which the scale of the city, and particularly mayoral governance, assumes a privileged role (McNeill 2001; 2004, 90-120; Brenner 2004). It might equally recall the notion of 'cityspace' as an extended conception of the urban that may also take in countryside and even wilderness areas (Soja 2000,16). More precisely, Boeri is interested in reimagining Europe on the scale of the city, not as a megalopolis (which he considers un-European), but as a polycentric mosaic of urban areas, parks, gardens, and waterways. Such a Europe is, he argues, an emerging fact of experience; not for everybody certainly, but for a cosmopolitan vanguard who must lead the way, just as the intellectual vanguard must lead with the Republic of Letters.

This mildly elitist stance has an old-fashioned ring to it that is, arguably, reflected in the form of the departures board itself. After all, Solari, or split-flap, boards of this design are themselves somewhat old fashioned, having been replaced in many airports with digital displays. In any case, the Solari board, with its neatly arranged columns of text, its contrast of crisp white characters and black background, its declarative, capitalised headings of "PARTENZE" and "DEPARTURES" (a commonly experienced instance of public translation), and its right-hand column of red lights, certainly offers an aesthetically more rich, and even performative, spectacle than is mustered by most digital departure boards. 
It has a mesmerising mechanical complexity and the whirring of its flaps creates an arresting and instantly recognisable sound. Unlike digital displays, where transition from one state to the next is often silent and unremarkable, the Solari board, not unlike an old-fashioned fruit machine, introduces dramatic tension as the spectator waits for the display to form each new configuration. In that sense it was a judicious choice for an installation that encouraged speculation about an unknown future. Furthermore, a board of this kind is readily apprehended as a sign of travel in a way that the digital screen - thoroughly ubiquitous in modern life - is not. This remains the case even, or perhaps especially, as these mechanical boards are gradually displaced from actual nodes of transport rather in the manner that images of older telephones and cameras have sometimes persisted as effective symbols for the newer forms that have replaced them. Indeed, the Solari's ability to produce artistic spectacle might be regarded as one more example of an object's aestheticisation occurring precisely at the moment of its obsolescence. This phenomenon, in which nostalgia plays no small part, here complicates and enriches the artwork. 'Tomorrow' is inflected with the melancholia of 'yesterday', lending the installation a compelling sense of temporal hesitancy.

This hesitancy is important and it points to further tensions within the work. Like Banksy's mural in Clacton-on-Sea, the installation uses flight to interrogate Europe's borders. The mural denaturalises the border and, as it were, paints it as absurd. The Solari board instead celebrates changing understandings and experiences of borders, which it considers to signal the emergence of a new Europe; both as an experiential fact and as a future that we must work to realise. Given the location of the installation, in an exhibition exploring Italy's modernity, it is difficult not to recall the work of the Futurists, one of the country's earliest and best known modern movements, whose preoccupation with dynamism is an ancestor of the installation's celebration of mobility across distances shrunken by speed. The Futurists were similarly enthralled by flight, although they valued it not so much for the purposes of forging connections between peoples as for its dizzying, mechanical thrill and its potential to expand the borders of empire. Politically antithetical to Futurism, the installation - and indeed the Tomorrow, as its name suggests - nevertheless shares with it a marked orientation towards the future. This is underpinned in the installation by its association with the New Narrative for Europe, a declaredly teleological initiative that relies on a broadly historicising narrative of the past (in terms of European integration) in order to project forward to a desired future.

The creation of such a narrative necessarily involves reduction and the loss of historical grain and texture - a process that, in this case, is difficult to sustain. After all, at the same time that the New Narrative for Europe called, through its declaration, for a cosmopolitan Europe-city, making only brief mention of economic crisis and asserting that the European Union "took action to accelerate [the] shift towards stronger political governance of the financial systems" (Battista and Setari 2014, 128), the existence of compelling counter narratives - narratives not aimed at an idealising horizon but grounded instead in the grinding reality of crisis - were everywhere to behold. As Dina Vaiou 
observed, in an article published in City during the period in which the Biennale was held, the failure of the Troika of the International Monetary Fund, European Commission and European Central Bank in Greece was already clear to behold:

\footnotetext{
It seems that the small and peripheral Greek economy has provided an easier site for neo-liberal experimentation on a number of frontal attacks: to demolish whatever there is of a welfare state and abolish workers' rights, pension systems, wages and salaries; to reform an economy based on SMEs (small and medium-sized enterprises) and self-employment, and discredit informal practices of getting by; to attack the public sector and its tight links with family strategies and to marginalise democratic sovereignty (Vaiou 2014).
}

As Vaiou noted, "the promised recovery is postponed to an unknown future." In this context both the new Narrative for Europe's declaration, and the celebration of a borderless, cosmopolitan Europe-city appear naïve and untenable. It is a state of affairs (and here we must bear in mind once again that it is the work that the installation performs, rather than the intentions of its authors that is at issue) that seems to find voice in the installation's own hesitation: its simultaneous forward march and backward glance. Rather like Walter Benjamin's angel of history, imagined through a description of Paul Klee's Angelus Novus of 1920, the flight evoked by the installation seems to be of a kind that is propelled forwards by the irresistible winds of progress, rendering impossible the troubled looking back that events themselves demand (Benjamin 1968, 257-8).

\section{Centres and Peripheries}

Both of the works discussed here have had, and continue to have, their afterlives. Banksy's mural in Clacton heralded a period of broader engagement with the British seaside, manifested above all in the so-called "bemusement park" of Dismaland in Weston-super-Mare. Following its closure, materials were shipped from Dismaland to Calais, to be used in the construction of shelters for migrants living in desperate conditions on the French coast. A number of artworks also appeared in the area. Notable among these is a mural stencilled onto the side of a Calais medical centre that quotes from Théodore Géricault's The Raft of the Medusa of 1819; a kind of a small scale, abbreviated, monochrome reproduction of the painting (fig 3). Here the shipwrecked mariners try to wave down a boat as it speeds past them on the horizon. Unlike in the original painting, where the ship is nothing more than a distant speck, Banksy makes his craft large and clear: a luxury yacht complete with helicopter and helipad. The mural thus employs the absolute binaries typical of Banksy's work; a reductive tendency that has caused some to regard his images as the equivalent of visual slogans, lacking the kind of ambiguity and nuance proper to searching and reflective works of art. 


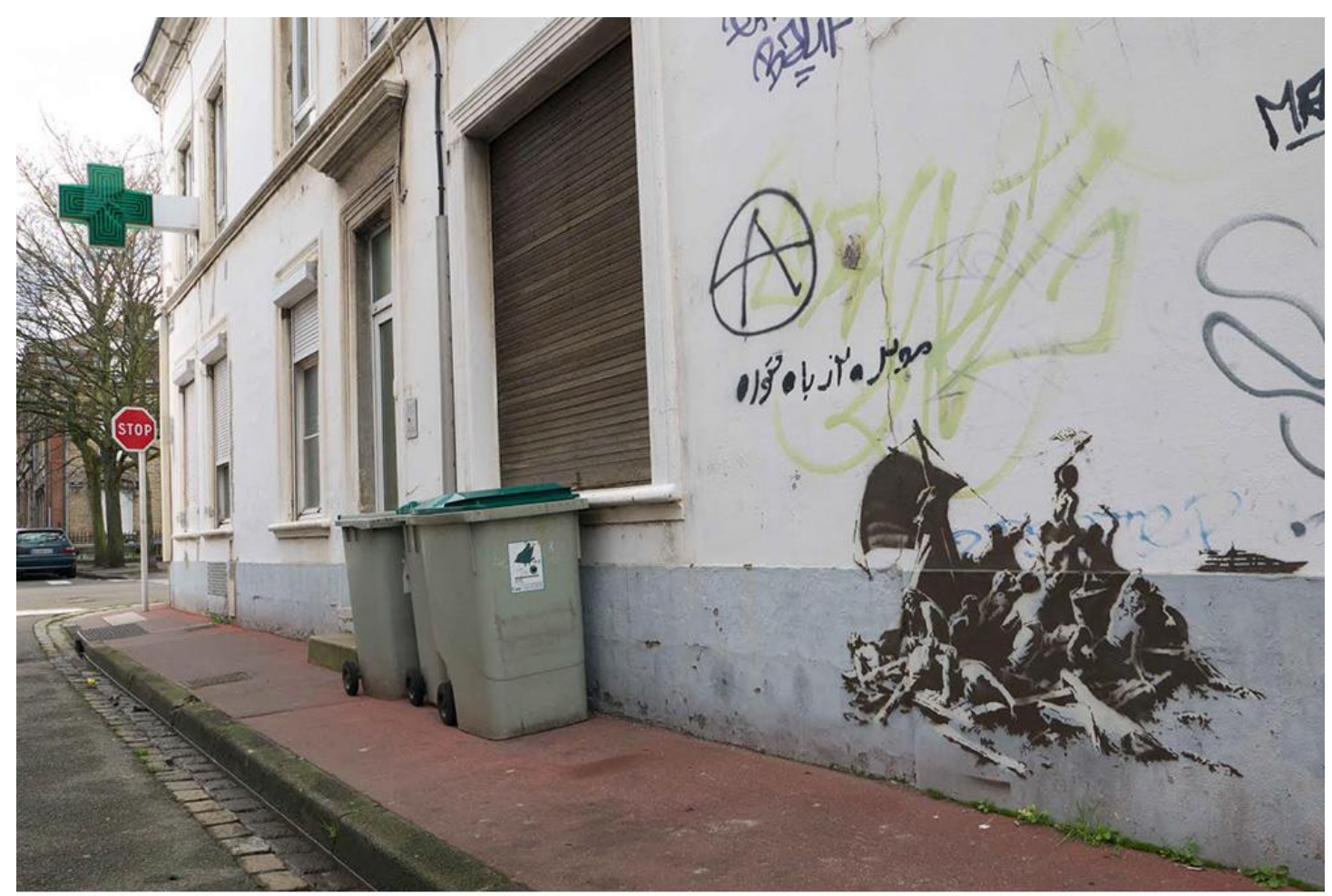

Figure 3. Banksy, mural in Calais, 2015.

Be that as it may, the work does perform a number of interesting functions. Its repurposing of one of the Louvre's best-known old master paintings is a move that is familiar from Dada and Pop, as is the mixing of socalled high art and popular culture. There is perhaps a staged desire here, on Banksy's part, for self-identification with Géricault as a politically engaged artist who, as it were, lived his work. The Raft of the Medusa is a painting that represents a scandalous episode in French history in which powerful men of rank callously abandoned their social inferiors to a horrific fate. ${ }^{6}$ The mural recalls the racist violence (specifically British and French in this case) of Europe's colonial past, since the frigate Medusa ran aground on its way to complete the transfer of the Island of Saint-Louis, off the coast of Senegal, from British to French control. The mural speaks directly to the French national psyche by employing one of its most hallowed images. It also addresses the British psyche by bringing to the border a work that many who pass through Calais will journey onwards to see in Paris, and by attempting to reactivate the original moral and political significance of that work; treating it not simply as a 'masterpiece' and a spectacle for tourists but as a profound piece of visual thinking about power, injustice, and humanity subjected to physical and moral extremes. The mural thus looks through time towards both the past and the present. It also looks through space, towards both the French capital (where Géricault's painting hangs) and back across the channel to the UK.

The mural highlights not only the indifference of the rich world in relation to the poor but also the variable quality of the border between Britain and France - an internal EU, non-Schengen, 'hard' border through which some pass 
with ease (the artist's own work on either side of the border is itself an example of this) while others meet almost total resistance. As the Clacton mural looked out across the Channel to continental Europe, this mural looks figuratively back across the border to Britain. It is a game of looking that is amplified by another work in Calais in which a boy with a suitcase, presumably a refugee, peers out to sea through a telescope on which has settled a large vulture - returning, as it were, the dolorous gaze that the Clacton painting directed towards the Netherlands (fig 4). Again, the work looks not only through space but also through time. The child is reminiscent of a refugee of the 1940s, the period of Europe's last great refugee crisis. And once again the work, quite literally in regards to the figure of the boy, looks in one direction and is blown in the other in this case gazing forwards but blown strongly backwards by a wind that takes hold of the child's hair but leaves the vulture entirely unruffled. The ocular web of cross-border gazes is extended further in the Raft mural. With its scene of shipwreck, this work looks still further through European space, collapsing this northerly border into the borders of Europe's southern periphery, where the shipwreck and drowning of refugees is a frequent, tragic occurrence.

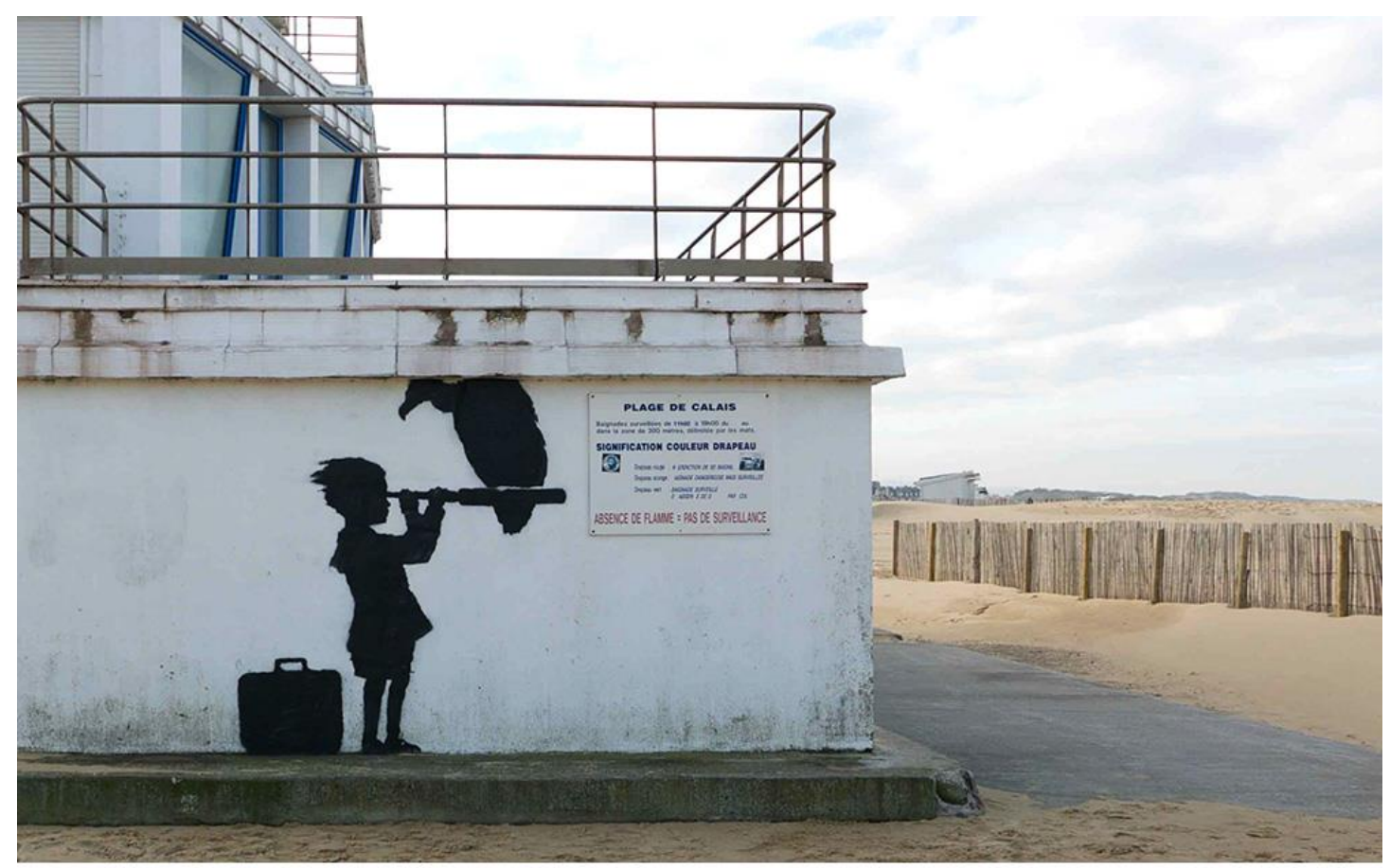

Figure 4. Banksy, mural in Calais, 2015.

Like the Clacton work, the Raft mural makes use of its ground and utilises a pre-existing line in the building's surface. The lower portion of the building effectively evokes the grey waters of the channel and the positioning of the stencil sets the horizon high. As such, the mural responds to Géricault's work, in which the tall horizon and the towering waves powerfully convey the sense of being lost in a wide and undifferentiated stretch of ocean, while simultaneously being immersed in and almost buried beneath the claustrophobic weight of the 
sea. In the mural, the yacht speeds away above the horizon, in a zone of bright, if graffitied, sky - frictionless and almost entirely untouched by the grey wastes beneath it, its sharp hull and the tail fin of its helicopter positively bristling with conspicuous signs of mobility. Géricault's heavy clouds and variegated light give way here to the characteristic binary of Banksy's two opposing zones - a reductive move but one that draws attention to the horizon. While in the Raft the horizon is partly obscured by a wave, powerfully adding to the feeling of disorientation, in the mural, it is the horizon, and thus the line, that emerges as the focus of pictorial enquiry.

The two murals in Calais and Clacton are thus both distinguished by what might be called their 'line of enquiry.' Almost every academic discussion of borders argues that they should no longer be conceived of only as lines (if in fact they ever were). However, while geography might take pains to distinguish between borders and boundaries in academic discourse, lines are still among the most powerful cultural signifiers of borders. Lines are also the province of artists - one of their most important provinces according to a long tradition that stretches back to Pliny's the Elder's account of Protogenes recognising Apelles's work from the quality of a single line and the two ancient Greek artists then competing to draw the finest line possible (Natural History XXXV.88, 81). This tradition continues through the Renaissance, with Leon Battista Alberti's notions of circumscriptio (circumscription) in painting and lineamenta (lines and angles) in architecture, and Giorgio Vasari's emphasis on the importance of draftsmanship (disegno) for all of the arts (Alberti 1972 and 1988; Vasari, 1996). Entering into British art theory, it is manifested in, for example, Hogarth's line of beauty and the 'expressive' lines of Roger Fry's formalism (Hogarth 1997; Fry 1918 and 1919; for an anthropological consideration of lines see Ingold 2007). Artists have often been drawn to the simultaneous fixity and ambiguity of lines and it is perhaps not surprising that, in a lecture on frontiers delivered in 1907, when the modern concept of the border was still being fashioned, Lord Curzon suggested that "the evolution of Frontiers is perhaps an art rather than a science, so plastic and malleable are its forms and manifestations" (Curzon, 1907; Walters 2002). The murals in Clacton and Calais, structured around 'found' lines in the plastic and malleable surfaces of buildings, evoke the ability of art to think visually about the nature of borders, to make manifest the ways in which we can work to see or to un-see them, and thereby to draw out their inherent ambiguity.

The New Narrative for Europe has also continued to inspire artworks, most recently in a large exhibition held at Bozar, in Brussels, from April $13^{\text {th }}$ to May 29th 2016. Titled Imagine Europe: In Search of New Narratives, this extensive exhibition incorporated works by many participants, including artists, architects, students, and school children. It included much fine grain examination of Europe from heterogeneous perspectives, creating an atmosphere that was more meditative and reflective - often, in fact, sombre and forlorn - than idealistic or visionary. The refugee crisis, in particular, weighed heavily upon it, and while generalising, idealistic perspectives were present, they were to some extent undercut by other views - most effectively in two refreshingly confrontational video installations by the Angolan artist and Belgian resident Nástio Mosquito. These videos, and in fact the entire exhibition itself, would require an extensive 
analysis. Here, however, I would like briefly to consider only one work: the installation BERL 13/057, created by Rem Koolhaas, the curator of the 2014 Venice Biennale, in collaboration with AMO, the research branch of the Office for Metropolitan Architecture (OMA).

The installation (fig. 5) was a replica of the office of the President of the Europe Commission, Jean-Claude Juncker, the original of which is located in the Berlaymont building about two kilometres from Bozar. Juncker's domain was presented as a cosy, low-ceilinged affair, modest but ample, with warm lighting and a predominance of wooden surfaces. The visitor could range around the full extent of the room, observing the videos playing on the six flat screens, perusing the papers spread over the desk, and examining Juncker's book collection. Koolhaas has a long and enduring relationship with the EU, working, in various ways, on the problem of what he has termed its "iconographic deficit" (Koolhaas 2004, 376-389; see also McNeill 2006; Oittinen 2012; Jencks and Koolhaas 2011, 41-44); an example of his view that "architectural thinking" might profitably be expanded beyond the borders of architecture itself (Cunningham and Goodbun 2009, 37-38). As part of a 2001 initiative to consider how Brussels might be made an effective capital of Europe, Koolhaas had argued for a 'hard' capital that would be brought about partly through decisive architectural and urbanistic interventions (European Commission 2001). The installation might be understood in the same vein. In a manner characteristic of OMA/AMO, it rather flies in the face of what has become standard thinking, eschewing the much debated notions of the EU as polycentric, dispersed, networked, and so on, to focus instead on the centre as traditionally understood. The EU is not an abstraction but a concrete reality, instantiated in places. Where the Tomorrow's installation speaks to mobility across a polycentric Euro-city, and engages above all with European space, Koolhaas/AMO's work focuses on place in all its specificity and particularity: not a city or a building but a single room, BERL $13 / 057$. The centre is by no means everywhere in this installation. On the contrary, it is somewhere and we are offered a chance to see what the view from the centre looks like. 


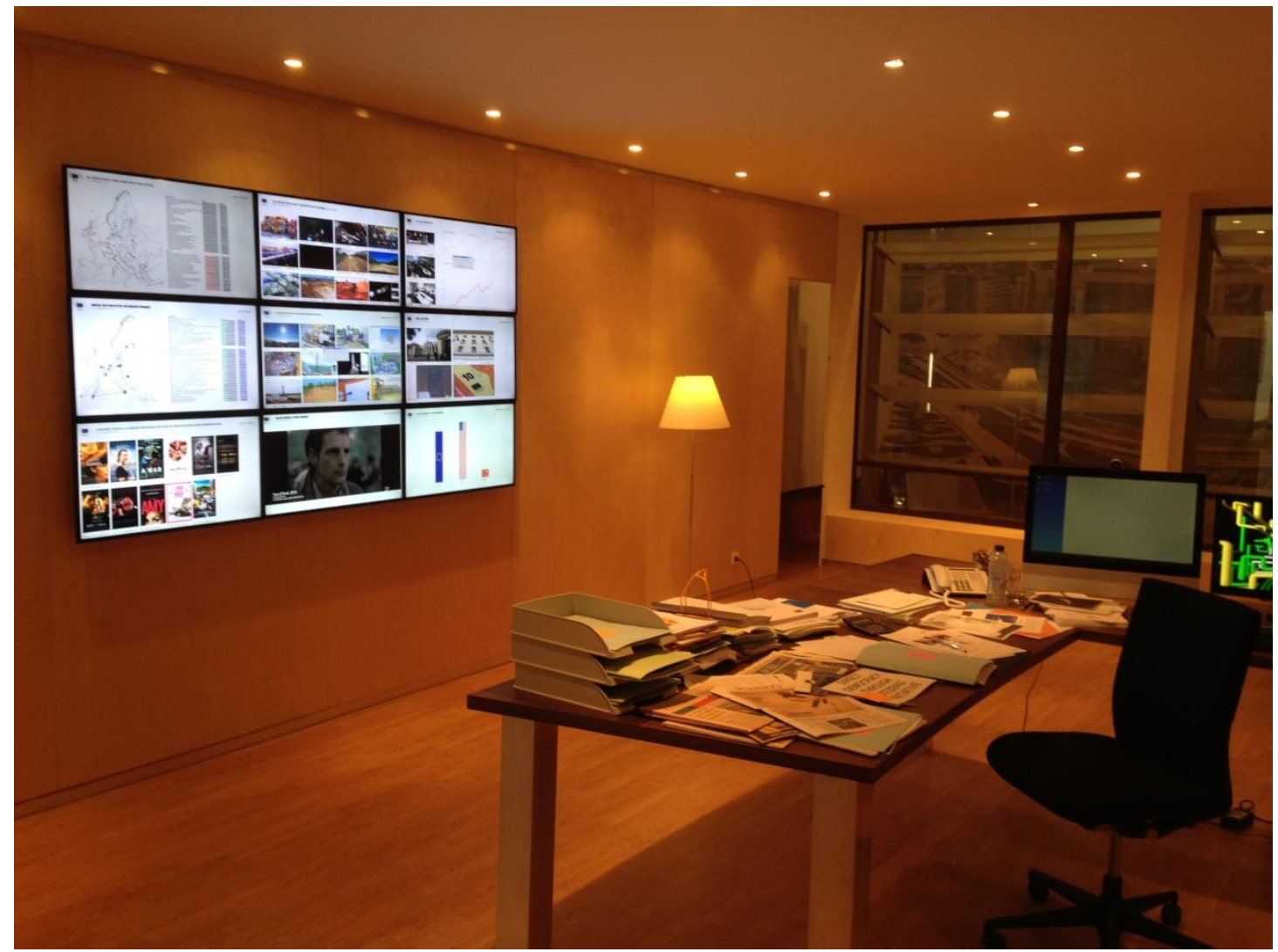

Rem Koolhaas and AMO, BERL 13/057, Bozar, Brussels, 2016.

BERL 13/057 seems to make a rather bold statement in this sense.

However, it is also infused with a considerable degree of uncertainty. There are plentiful quantities of AMO/OMA's characteristic irony on display here, such as the locked safe labelled 'PLAN B' and the dossier on the desk with the heading "DIRECT DEMOCRACY THROUGH CITIZENS' INITIATIVE," to which a post-it note has been appended reading "IMPORTANT". Indeed, a closer look at Juncker's bookshelf raises doubts about what is on display. Does Juncker really have a copy of Fredric Jameson's Postmodernism, or the Cultural Logic of Late Capitalism on his shelves? Does the collection of animal fables by Anton Koolhaas, Vergeet niet de leeuwen te aaien (Don't Forget to Pet the Lions) of 1957, belong to Juncker or to Anton's son Rem? And if we wonder about these details, how certain can we be about any of the installation? To what extent is this a replica and to what extent a reinterpretation? Without entering into the extensive debates about replication in art, it is worth noting here simply that the installation plays on our doubts about the relationship between copy and original. Just as it is sometimes hard to pin down Koolhaas's own position- which often seems to combine the stances of detached observer, ironic critic, and participant - so it is hard to pin down the position of the installation. We are presented with the centre - but how seriously? Is the centre solid or is it a simulacrum spun from illusion and irony, complete with jokey references to its own postmodernity?

\section{Conclusion}

The works under discussion here address the European imaginary in a variety of ways. All of them engage with Europe's spaces and places and all of 
them can be understood in relation to the complex issue of European borders. Banksy's stencilled murals are not part of an effort to imagine Europe and nor are they concerned directly with the EU. Rather, their imagery addresses national audiences and is also suited to rapid circulation in national and global media. Nonetheless, in its investigation of the border, and indeed the nature of borders, and in the gaze that it casts between Britain and France, and beyond to Europe's southern borders, Banksy's work does constitute an examination of European space. On the level of iconography the murals are simple, and perhaps even simplistic. In the case of Clacton, the work seems to bring national and international scales crashing into a local environment with little awareness or sensitivity. Yet the murals function in other ways also and ultimately work to denaturalise British and European borders through a form of visual thinking about places and their boundaries.

The Tomorrow's installation also serves to denaturalise the border. However, where Banksy's murals critique the power relations instantiated in Europe's borders, this installation - made in support of the EU and as a result of one of its initiatives - celebrates what is sees as the unfolding reality of a new form of European space. The installation seems to adopt a number of ideas that are current in the discourses of academics and officials; it advocates for a vision of the future at the same time that it draws attention to something that we already perhaps experience. It suggests the relative quality of distances, which ought not always be measured only in the fixed units of miles and kilometres but also in terms of interests and ideas (Anderson 1996). It seems to probe the phenomenon of the Schengen zone; the very existence of which itself arguably serves to denaturalise national borders, causing us to reflect on them and to confront their historicity and contingency (Walters 2002). In this sense, the installation signals that travel through Europe might be paralleled to aesthetic experience itself (the presumed 'distancing' and denaturalising qualities of which the New Narrative for Europe perhaps sought to harness).

The installation by Koolhaas/AMO, on the other hand, makes a radical statement precisely by withdrawing from the issue of borders and mobility, and by drawing our attention to another reality: the existence of a fixed centre. In a public conversation at Bozar, held to mark the opening of the Imagining Europe exhibition, Koolhaas conjectured that Europe does not really need to be imagined at all. Indeed, he suggested, the more that it is wrapped up in metaphorical language, and the more that it clothes itself in rhetoric, the less tangible it really becomes. ${ }^{7}$ The European Union is already a concrete fact; one that might best be experienced directly rather that shrouded in the discourses of polycentrism, monotopias, borderlands, and so forth (Rumford 2006). However, the installation leaves the question of the centre's true substance unresolved.

Responding to the crisis in the Eurozone, Jürgen Habermas noted that "the cunning of economic (un)reason has placed the question of the future of Europe back on the political agenda" (Habermas 2013). Difficult though times were, he conjectured, it was still possible that a sense of a shared Europeanness, and indeed a shared European destiny, might emerge from them. The works examined here can hardly be taken as evidence for the existence of a European 
public sphere of the kind that Habermas believes necessary for the success of the European project (Habermas 1992; 2001). The installations perhaps aim to bring such a public sphere into existence, while Banksy's works may be understood as having a 'horizontal', transnational character, speaking to different national publics across their shared borders. In the wake of the UK's vote for Brexit, however, the issues probed by the artists and architects in these works have come to the fore in an extraordinary manner. Among the many ramifications of what some regard as "the most disastrous development in the UK's political and economic history since 1945" (Sanders, 2016) the destabilisation of the border between Britain and France has received a great deal of attention, with much discussion of the potential movement of the UK's southern border back across the Channel to England. Meanwhile, concerns regarding varying attitudes towards, and access to, mobility in Europe have increasingly impinged upon public debate, while the strength of the EU's centre and its ability to react to events continues to be the object of intense scrutiny. As a result, the daunting task of imagining both Europe and the UK has become more vital than ever, even as it has become exponentially more complex.

\section{Bibliography}

Alberti, L. B. A. 1972. On painting and On Sculpture: the Latin Texts of De pictura and De Statua. Edited with translations, introduction and notes by Cecil Grayson. London: Phaidon.

Alberti, L. B. A. 1988. On the Art of Building in Ten Books. Cambridge, Mass.: MIT.

Alhadeff, A. 2002. The Raft of the Medusa: Géricault, Art, and Race. Munich: Prestel.

Amilhat Szary, A-L. 2012. "Walls and Border Art: the Politics of Art Display." Jurnal of Borderland Studies 27 (2): 213-228.

Anderson, J. 1996. “The Shifting Stage of Politics: New Medieval and Postmodern Territorialities?" Environment and Planning D: Society and Space 1996 (14): 133153.

Anderson, B. 1983. Imagined Communities: Reflections on the Origin and Spread of Nationalism. London: Verso.

Anderson, P. 2011. The New Old World, London: Verso.

Angelo, H. and Hentschel, C. 2015. "Interactions with Infrastructure as Windows Into Social Worlds: a Method for Critical Urban Studies: Introduction." City: Analysis of Urban Trends, Culture, Theory, Policy, Action 19 (2-3): 306-312.

Balibar, E. 2014. "At the Borders of Europe from Cosmopolitanism to Cosmopolitics." Translation (spring): 83-103. 
Battista, E., and Setari, N. (eds.) 2014. The Mind and Body of Europe: a New Narrative. Brussels: European Union.

Bazin, G. 1987-1997. Théodore Géricault. Etude critique, documents et catalogue resonné. 7 vols. Paris: La Bibliothèque des arts.

Benjamin, W. 1968. Illiminations. Edited with an introduction by Hannah Arendt, translated by Harry Zohn. New York: Schocken Books (1969 reprint).

Bialasiewicz L., and Elden, S. 2006. "The New Geography of Division and the Problem of a Kantian Europe." Review of International Studies 32: 623-644.

Brenner, N. 2004. New State Spaces: Urban Governance and the Rescaling of Statehood. Oxford: Oxford University Press.

Centre for Social Justice (2013). Turning the Tide: Social Justice in Five Seaside Towns. London: The Centre for Social Justice. Accessed June $5^{\text {th }} 2016$. http://www.centreforsocialjustice.org.uk/UserStorage/pdf/Pdf\%20reports/Tur ning-the-Tide.pdf

Cresswell, T. 2006. On the Move. Mobility in the Modern Western World. New York: Routledge.

Cresswell, T. 2010. "Towards a Politics of Mobility." Environment and Planning D: Society and Space 28: 17-31.

Cunningham, D., and Goodbun, J., 2009. "Propaganda architecture: interview with Rem Koolhaas and Reinier de Graaf." Radical Philosophy 154: 35-47.

Derrida, J. 1992. The Other Heading: Reflections on Today's Europe. Bloomington: Indiana University Press.

Derrida, J., and Venuti, L. 2001. "What is a "Relevant" Translation?" Critical Enquiry 27 (2):174-200.

European Commission 2001. Brussels, Capital of Europe: Final Report. Accessed June $11^{\text {th }} 2016$.

http://ec.europa.eu/dgs/policy_advisers/archives/publications/docs/brussels_ capital.pdf

Fairey, S. 2010. "Banksy." Time Magazine. Accessed June 11 $11^{\text {th }} 2016$. http://content.time.com/time/specials/packages/article/0,28804,1984685_198 4940_1984945,00.html

Ford, R, and Goodwin, M. 2014. "Understanding UKIP: Identity, Social Change and the Left Behind." The Political Quarterly 85 (3): 277-284.

Fry, R. 1918. "Line as a Means of Expression in Modern Art." The Burlington Magazine for Connoisseurs 33 (189): 201-3, 205-8. 
Fry, R. 1919. "Line as a Means of Expression in Modern Art (Continued)." The Burlington Magazine for Connoisseurs 34 (191): 62-63, 66, 67, 69.

Geddes, A. 2014. "The EU, UKIP, and the Politics of Immigration in Britain." The Political Quarterly 85 (3): 289-295.

Giudice, C., and Giubilaro, C. 2015. "Re-imagining the Border: Border Art as a Space of Critical Imagination and Creative Resistance." Geopolitcs 20 (1): 79-94.

Goodwin and Milazzo. 2015. UKIP: Inside the Campaign to Redraw the Map of British Politics. Corby: Oxford University Press.

Habermas, J. 1992. The Structural Transformation of the Public Sphere: An Inquiry into a Category of Bourgeois Society. Cambridge: Polity Press.

Habermas, J. 2001. "Why Europe Needs a Constitution." New Left Review 11: 5-26.

Habermas, J. 2013. The Crisis of the European Union: a Response. Cambridge: Polity, 2012.

Hogarth, W. 1997. The Analysis of Beauty. Edited with an introduction and notes by Ronald Paulson. New Haven: Yale University Press.

Ingold, T. 2007. Lines: a Brief History. Oxon: Routledge.

Jencks, C., and Koolhaas, R. 2011. "Radical Post-Modernism and Content: Charles Jencks and Rem Koolhaas Debate the Issue." Architectural Design 81 (5): 32-45.

Jerolmack, C. 2008. "How Pigeons Became Rats: The Cultural-Spatial Logic of Problem Animals.” Social Problems 55 (1): 72-94.

Jones, J. 2014. "Banksy Wanted Clacton-on-Sea to Confront Racism - Instead it Confronted Him." The Guardian. Accessed June $1^{\text {st }} 2016$.

http://www.theguardian.com/commentisfree/2014/oct/02/bansky-clacton-onsea-racism-tendring-district-council-destroyed-immigration

Kaiser, W. 2015. “Clash of Cultures: Two Milieus in the European Union's 'A New Narrative for Europe' Project.” Journal of Contemporary European Studies, pp. 114.

Kølvraa, C. 2016. "European Fantasies: On the EU's Political Myths and the Affective Potential of Utopian Imaginaries for European Identity." Journal of Common Market Studies 54 (1): 169-184.

Koolhaas, R. 2004. Content. Köln: Taschen.

Koolhaas, R. 2014. fundamentals catalogue. Marsilio: Venice. 
Lindberg, S., Ojakangas, M., and Prozorov, S. 2014. Europe Beyond Universalism and Particularlism. Houndmills, Basingstoke: Palgrave Macmillan.

Maas, W. 2007. Creating European Citizens. Lanham Md.: Rowman \& Littlefield.

Masden, K. 2015. "Graffiti, Art and Advertising: Re-Scaling Claims to Space at the Edges of the Nation State." Geopolitics 20 (1): 95-120.

McNeill, D. 2001. "Embodying a Europe of the Cities: Geographies of Mayoral Leadership." Area 33 (4): 353-359.

McNeill, D. 2004. New Europe: Imagined Spaces. London: Arnold.

McNeill, D. 2006. “Performing European Space?" European Urban and Regional Studies 13 (1): 83-87.

Multiplicity (2003). USE: Uncertain States of Europe: a Trip through a Changing Europe. Milan: Skira Editore.

Oittinen, R. 2012. “Cosmopolitan Versus Nationalist Visions: Rem Koolhaas's Exhibition The Image of Europe." In Heritage, Ideology and Identity in Central and Eastern Europe: Contested Pasts, Contested Presents, edited by Matthew Rampley, 175-194. Woodbridge: The Boydell Press.

Pritchett, V. S. 1945. New Statesman and Nation, vol. xxix, no. 724, $6^{\text {th }}$ January.

Rumford, C. 2006. "Rethinking European Spaces: Territory, Borders, Governance.” Comparative European Politics 2006 (4): 127-140.

Sanders, D. 2016. "Letter to David Cameron - split your party and start a new one to save Britain." The Conversation. Accessed July 11th 2016.

http://theconversation.com/letter-to-david-cameron-split-your-party-and-starta-new-one-to-save-britain-61893

Schmitter, P. C. 1996. "Examining the Present Euro Polity with the Help of Past Theories." In Governance in the European Union, edited by Gary Marks, Fritz W. Scharpf, Philippe C. Schmitter, Wolfgange Streeck, 1-14. London: Sage.

Soja, E. 2000. Postmetropolis. Maldon, MA: Blackwell Publishing.

Tendring District Council 2010. Celebrate-on-Sea. Accessed June $1^{\text {st }} 2016$. http://www.tendringdc.gov.uk/sites/default/files/documents/business/regene ration/clacton/Celebrate $\% 20$ on $\% 20$ sea $\% 20$ reduced $\% 20$ file $\% 20$ size.pdf

Vaiou, D. 2014. "Is the crisis in Athens (also) gendered?: Facets of Access and (in)Visibility in Everyday Public Spaces." City 18 (4-5): 533-537. 
Van Houtum, H. 2005. "The Geopolitics of Borders and Boundaries." Geopolitics 10: 672-679.

Vasari, G. Lives of the Painters, Sculptors and Architects. Translated by Gaston du C. De Vere. New York: Everyman.

Walters, W. 2002. "Mapping Schengenland: Denaturalizing the Border." Environment and Planning D: Society and Space 2002 (20): 561-580.

Walters, W. 2009. “Europe's Borders." In Sage Handbook of European Studies, edited by C. Rumford, 485-505. London: Sage.

Walters, W. 2009. “Europe's Borders." In Sage Handbook of European Studies, edited by C. Rumford, 485-505. London: Sage.

\footnotetext{
1 "un objet politique non-identifié."

${ }^{2}$ All of these figures relate to the period 2010-2011.

${ }^{3}$ Jerolmack 2008, 80-81, credits New York City Parks Commissioner Thomas P. Hoving with the first use of the phrase "rats with wings" in 1966. Discussing the restoration of Bryant Park, Hoving and the park supervisor described the pigeons as "vandals" while also decrying the presence of litterers, homeless people and homosexuals in the park.

${ }^{4}$ This form of words was used in the wall text relating to the installation.

${ }^{5}$ the Tomorrow's web journal is available at http://thetomorrow.net/about/

${ }^{6}$ There is a vast art historical, scholarly literature on the Raft of the Medusa. Theodore Bazin's monumental work (1987-1997, 6: 19-20) includes a summary of the bibliography up to the end of the last century. For a recent major study in English see Alhadeff 2002.

${ }^{7}$ A recording of the event is available at: https://www.youtube.com/watch?v=H4LM_kviiv4
} 